\title{
Fabry's Disease
}

\author{
Haruka Kato, Kenichi Sato, Susumu Hattori, Suguru Ikemoto, Mitsuyuki Shimizu and Yukihide Isogai
}

\begin{abstract}
A 20-year-old man presented with generalized acquired anhidrosis and heat intolerance which was confirmed by a sweat test. Other clinical features included severe pain of the extremities and cutaneous angiokeratomas. On electronmicroscopy, granules specific for Fabry's disease were observed in the endothelial cells. Biochemical examination revealed a decreased level of serum $\alpha$-galactosidase A. These findings confirmed the diagnosis of Fabry's disease. (Internal Medicine 31: 682-685, 1992)
\end{abstract}

Key words: $\alpha$-galactosidase A, ceramide trihexoside, angiokeratoma corporis diffusum

\section{Introduction}

Fabry's disease was first described by Fabry (1) and Anderson (2) in 1898. It is a rare, sex-linked recessive inborn error of lipid metabolism (3). The metabolic defect is a deficiency of $\alpha$-galactosidase A (ceramide trihexosidase), which results in the accumulation of ceramide trihexoside $(\mathrm{CTH})$ in various tissues, especially in endothelial cells $(4,5)$. Clinical features include painful attacks of extremities, skin lesions, anhidrosis and cardiac, cerebral, and renal vascular manifestations. The diagnosis is confirmed by a decreased activity of $\alpha$-galactosidase A and histologic findings. In Japan, the first case was described by Taguchi in 1938 (6). In this report, we present a typical case of Fabry's disease and review the existing literature on Fabry's disease in Japan.

\section{Case Report}

A 20-year-old man was admitted to the hospital on July 9,1990 because of generalized acquired anhidrosis and episodes of severe pain of the extremities. He first noticed dark red eruptions scattered on his back at 11 years of age. The lesions had gradually spread to the extremities and inguinal region. At 15 years of age he began to have attacks of severe pain in his extremities and noticed decreased sweating. At age 20, he began to have difficulty exercising due to rise in body temperature associated with generalized anhidrosis. These symptoms appeared often and required hospitalization occasionally.

Two years before he came to us, his mother died of renal dysfunction at the age of 55 . His younger sister, who was 12 years old, sometimes had bouts of slight pains in her extremities, which were similar to the patient's. Her attacks occurred during exercise or upon taking a bath. Hypohidrosis was not found.

On admission, the patient's stature and nutrition were within normal limits. The blood pressure was $120 / 80 \mathrm{mmHg}$, the pulse rate was 75 beats $/ \mathrm{min}$, and the body temperature was $37.2^{\circ} \mathrm{C}$. The skin was extremely dry and rough, and clusters of dark red eruptions were seen on his back, lower abdomen, inguinal region, and in regions on his extremities (Fig. 1).

Laboratory data were as follows; $\mathrm{Hb}, 15.5 \mathrm{~g} / \mathrm{dl}$. WBC, $4,500 / \mathrm{mm}^{3}$ with normal differential and platelet count. The serum enzyme activities were GOT, $7 \mathrm{mU} / \mathrm{ml}$; GPT, $7 \mathrm{mU} / \mathrm{ml}$; and $\mathrm{LDH}, 136 \mathrm{mU} / \mathrm{ml}$. The serum total protein was $7.3 \mathrm{~g} / \mathrm{dl}$ and the creatinine, $0.8 \mathrm{mg} / \mathrm{dl}$. The urinalysis was normal. The creatinine clearance was $58 \mathrm{ml} / \mathrm{min}$. The electrocardiogram and chest radiograph were normal. An ophthalmic examination revealed no specific findings in the cornea, lens, or retina. For the evaluation of anhidrosis and heat intolerance, the patient was exposed to heat. During the test there was no visible sweating.

Two biopsy specimens were taken, one from the left forearm which was free of any skin eruption, and one from a dark red eruption on his back. Figure 2 shows the histologic findings of the former, with a normal number of eccrine glands. Figure 3 shows the histopathology of the eruption indicating angiokeratoma. The epidermis overlying dilated blood filled vessels in the upper dermis was hyperkeratoratatic.

Electron microscopic examination demonstrated numerous electron-dense granules in the endothelial cells. Higher magnification revealed periodic laminations

From the Third Department of Internal Medicine, Jikei University School of Medicine, Tokyo

Received for publication July 25, 1991; Accepted for publication January 20, 1991

Reprint requests should be addressed to Dr. Haruka Kato, the Third Department of Internal Medicine, Jikei University School of Medicine, 3-25-8 Nishi-shinbashi, Minato-ku, Tokyo 105, Japan 


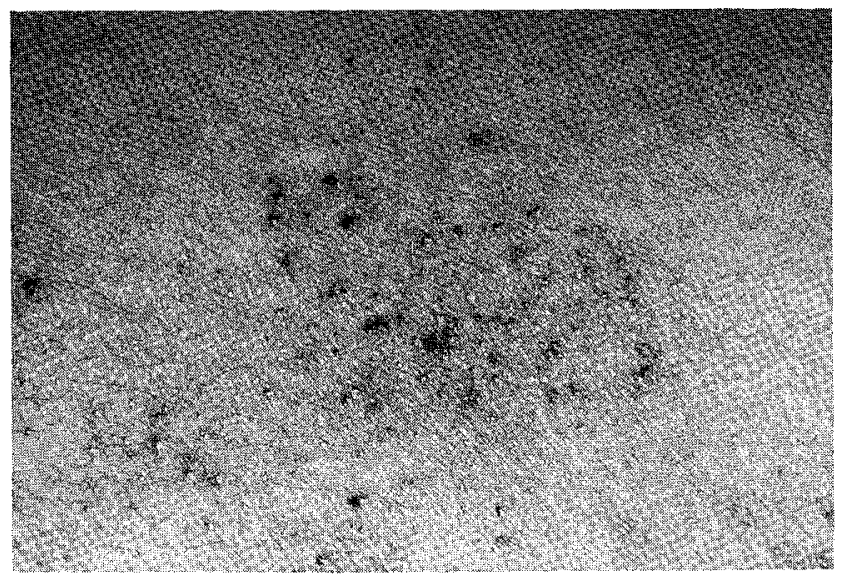

Fig. 1. Clusters of dark red eruptions in the lower abdomen.

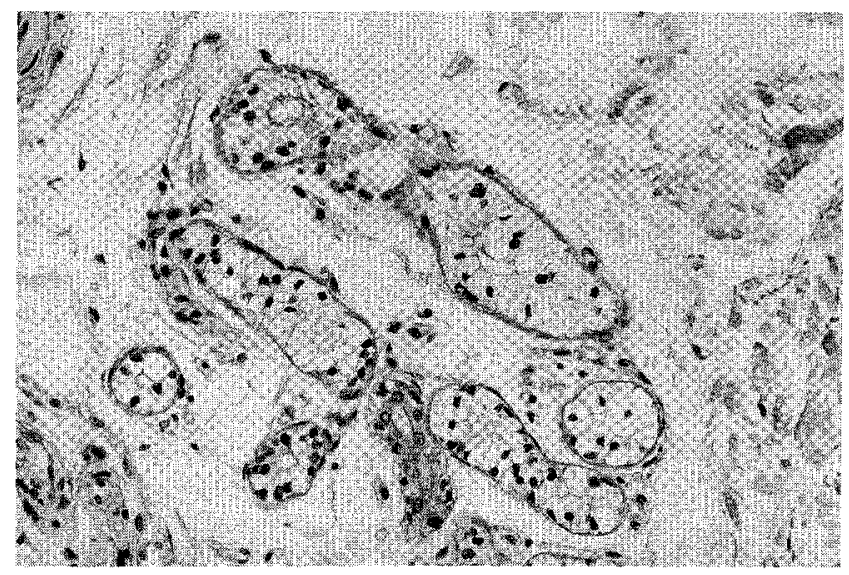

Fig. 2. Light microscopic examination of an eccrine gland $(\times 200)$.

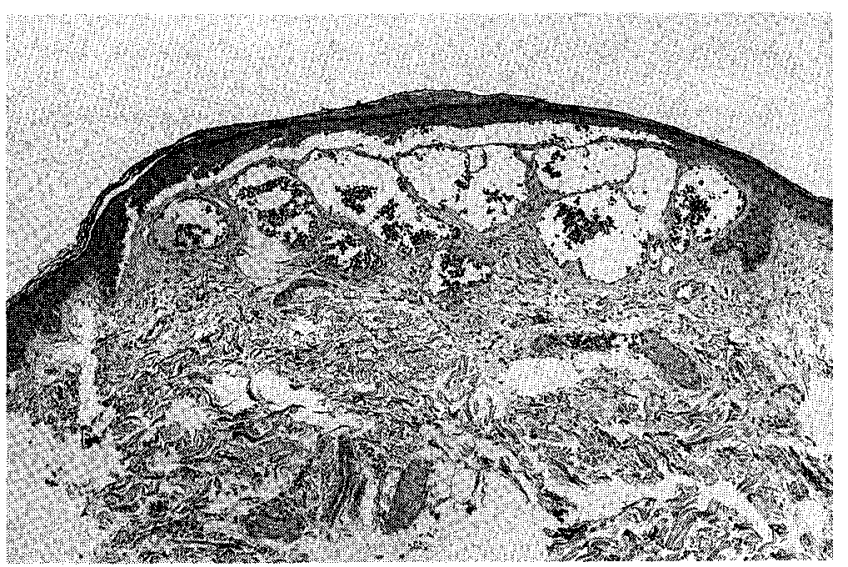

Fig. 3. Capillary dilatation in the papillary region of the dermis and hyperkeratotic epidermis $(\times 200)$.

with approximately 60-A intervals (Fig. 4). These clinical manifestations and histologic findings were specific for Fabry's disease.

To confirm the diagnosis we measured the leukocyte $\alpha$-galactosidase activity. The enzyme assay was performed

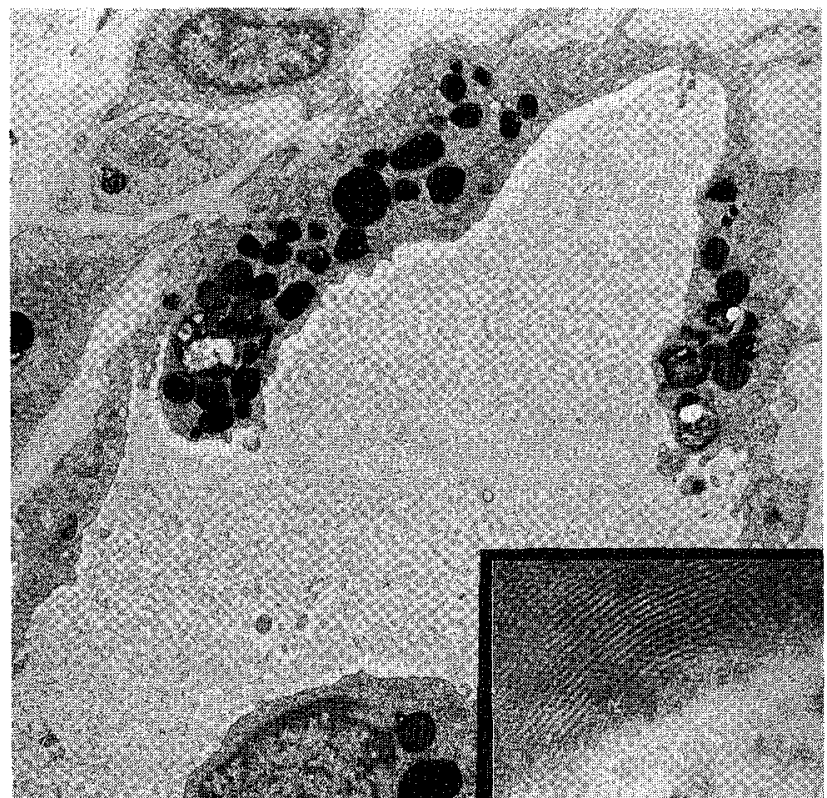

Fig. 4. Electron-dense granules in endothelial cells of a dermal blood vessel $(\times 11,600)$.

Inset: Higher magnification of an electron-dense granule showing regular lamellar structure $(\times 175,000)$.

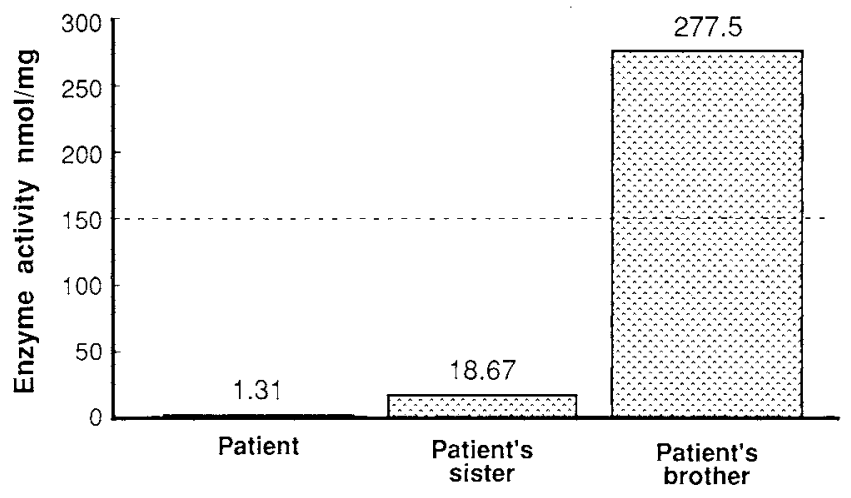

Fig. 5. $\alpha$-galactosidase A activity in leukocytes from the patient and his sistcr and brother (normal level is above the dotted line).

by means of 4-methylumbelliferyl- $\alpha$-D-galactoside. While, the normal value is from 150 to $250 \mathrm{nmol} / \mathrm{mg}$, the patient's enzyme activity was significantly lower than normal; his sister's enzyme activity was slightly decreased, and his brother's was normal (Fig. 5).

\section{Discussion}

Fabry's disease is a form of the glycosphyngolipidosis and is characterized by the accumulation of ceramide trihexoside (CTH) secondary to a deficiency of $\alpha$ galactosidase activity. CTH is deposited in all parts of body, predominantly in the lysosomes of vascular endothelial cells. The electron microscopic finding of characteristic intracytoplasmic lamellar granules in skin 
Table 1. Cases of Fabry's Disease Described in Japan from 1983 to 1991

\begin{tabular}{|c|c|c|c|}
\hline \multirow{2}{*}{$\begin{array}{l}\text { Date of } \\
\text { publication }\end{array}$} & \multirow[t]{2}{*}{ Author } & \multicolumn{2}{|c|}{ Number of patient } \\
\hline & & Male & Female \\
\hline \multirow[t]{3}{*}{1983} & Ko et al (12) & 9 & 9 \\
\hline & Kira et al (13) & 1 & \\
\hline & Nunoda et al (14) & & 1 \\
\hline 1984 & Suzuki et al (15) & 1 & \\
\hline \multirow[t]{2}{*}{1985} & Kobayashi et al (16) & 1 & \\
\hline & Ishii et al (17) & 1 & \\
\hline \multirow[t]{4}{*}{1986} & Sumi ct al (18) & 1 & 1 \\
\hline & Yamanaka et al (19) & 1 & \\
\hline & Tamura ct al (20) & & 2 \\
\hline & Aoyama et al (21) & 3 & 3 \\
\hline 1987 & Hozumi (22) & 4 & 3 \\
\hline \multirow[t]{7}{*}{1988} & Narisawa et al (23) & 1 & \\
\hline & Yamada et al (24) & 1 & \\
\hline & Tanaka et al (25) & 2 & 2 \\
\hline & Iwase et al (26) & 1 & \\
\hline & Tsuda et al (27) & & 3 \\
\hline & Matsuyoshi et al (28) & 1 & \\
\hline & Ujin et al (29) & 1 & \\
\hline \multirow[t]{3}{*}{1989} & Yoshida et al (30) & 3 & \\
\hline & Nakanishi et al (31) & 1 & \\
\hline & Yamamoto et al (32) & 1 & \\
\hline \multirow[t]{2}{*}{1990} & Yamada et al (33) & 3 & \\
\hline & Matsubara et al (34) & 4 & \\
\hline 1991 & Yamaguchi et al (35) & 2 & 2 \\
\hline
\end{tabular}

biopsy specimens is diagnostic of Fabry's disease $(7,8)$.

In this patient, Fabry's disease was suspected clinically due to the pain in his extremities, anhidrosis and characteristic skin lesions. This diagnosis was confirmed by the measurement of $\alpha$-galactosidase $\mathrm{A}$ activity in leukocytes and typical histologic findings. As the patient's sister had a significantly decreased enzyme activity, she is likely heterozygous for Fabry's disease gene. Although most biochemically documented heterozygotes have few symptoms, others have been reported to have severe cardiac or renal disease $(9,10)$. The patient's mother, who died of renal failure, may have been a heterozygote.

In Japan the first case of Fabry's disease was described in 1838. Sumida et al found that 96 patients comprising 39 family lines were present in Japan before 1982 (11). To our knowledge, 69 patients were reported from 1983 to 1991 (12-35) (Table 1). The clinical manifestations of these patients are shown in Table 2. Pain in the extremities, hypohidrosis, and skin lesions are common manifestations in the hemizygote. Ocular and cardiac involvement was found in less than $50 \%$ of male patients. Thus, it is interesting that cardiac involvement was frequent in heterozygotes. As some reports have suggested that deposits of CTH increase with age (36), the present patient may likely show additional symptoms. Therefore, it is necessary to follow these patients carefully.

Acknowledgments: The authors thank Dr. Etou and Dr. Inaba for their valuable comments.

\section{References}

1) Fabry J. Ein beitrag zur Kenntniss der Purpura haemorrhagica nodularis (Purpura papulosa haemorrhagica Hebra). Arch Dermatol Syphilol 43: 187, 1898 (in German).

2) Anderson W. A case of "angio-keratoma". Br J Dermatol 10: 113,1898 .

3) Kint JA. Fabry's disease: $\alpha$-galactosidase deficiency. Science 167: $1268,1970$.

4) Swcely GC, Klinsky B. Fabry's disease. Classification as a sphyngolipoidosis and partial characterization of a novel glycolipid. J Biol Chem 238: 3148, 1963.

5) Brady RO, Gal AE, Bradley RM, Martensson E, Warshaw AL. Enzymatic defect in Fabry's disease: Ceramide-trihexosidase deficiency. N Engl J Med 276: 1163, 1947.

6) Taguchi Y. Uber den ersten Fall von Angiokeratoma corporis diffusum in Japan. Dermatol Wschr 107: 1281, 1938 (in German).

7) Hashimoto K, Lieberman P, Lamkin N. Angiokeratoma corporis diffusum (Fabry disease) a lysosomal disease. Arch Dermatol 112: 1416, 1976.

8) Luderschmidt C, Wolff HH. Subtle clues diagnosis of skin diseases by electron microscopy: intra cytoplasmic granules with lamellae as signs of heterozygous Fabry's disease. Am J Dermatopathol 2: $57,1980$.

9) Ferrans VJ, Hibbs RG, Burda CD, et al. The heart in Fabry's disease: a histochemical and electron microscopic study. Am J

Table 2. Clinical Manifestations in Fabry's Disease Based on a Review of 53 Patients Described in Japan from 1983 to 1991

\begin{tabular}{|c|c|c|c|c|c|c|}
\hline Symptom & $\begin{array}{c}\text { Pain in } \\
\text { extremitics }\end{array}$ & $\begin{array}{l}\text { Hypo- or } \\
\text { anhidrosis }\end{array}$ & $\begin{array}{l}\text { Skin } \\
\text { lesions }\end{array}$ & $\begin{array}{l}\text { Ocular } \\
\text { features }\end{array}$ & $\begin{array}{c}\text { Renal } \\
\text { involvement }\end{array}$ & $\begin{array}{c}\text { Cardiac } \\
\text { involvement }\end{array}$ \\
\hline $\begin{array}{l}\text { Hemizygote } \\
n=42 \\
\text { age in years ( } n\end{array}$ & $\begin{array}{c}79 \% \\
=6-52(2\end{array}$ & $69 \%$ & $60 \%$ & $40 \%$ & $57 \%$ & $33 \%$ \\
\hline $\begin{array}{l}\text { Heterozygote } \\
\mathrm{n}=27 \\
\text { age in years ( } \mathrm{n}\end{array}$ & $\begin{array}{c}45 \% \\
=8-80\end{array}$ & $10 \%$ & $5 \%$ & $35 \%$ & $35 \%$ & $50 \%$ \\
\hline
\end{tabular}




\section{Fabry's Disease}

Cardiol 24: 95, 1969.

10) Desnick RJ, Simmons RL, Allen KY, et al. Correction of enzymatic deficiencies by renal transplantation: Fabry's disease. Surgery 72: 203, 1972.

11) Sumida S, Osawa M, Fukuyama Y, et al. A case report of Fabry's disease and review of the literature on 38 cases. Med Genet Res 5: 100, 1983 (in Japanese).

12) Ko $\mathrm{Y}$, Sakuraba $\mathrm{H}$, Yamanaka $\mathrm{T}$, et al. Ten family lines of Fabry's disease. J Jpn Pediatr Soc 87(6): 951, 1983 (in Japanese).

13) Kira J, Tahira T, Ohnishi K, et al. Atypical adult case of Fabry's disease without angiokeratoma and hypohidrosis (Biochemical and morphological studies). Clin Neurol 23: 450, 1983 (in Japanese).

14) Nunoda S, Genda A, Hifumi S, et al. A case of Fabry's disease, fifty-five years old female, diagnosed on the basis of endomyocardial biopsy findings. Heart 15(5): 591, 1983 (in Japanese).

15) Suzuki Y, Udagawa A, Masuzawa M, et al. Fabry's disease. Rinshouderma (Tokyo) 26(4): 383, 1984 (in Japanese).

16) Kobayashi $T$, Kira J, Shinnoh $N$, et al. Fabry's disease with partially deficient hydrolysis of ceramide trihexoside. J Neurol Sci 67: 179, 1985 (in Japanese).

17) Ishii A, Horiuchi $T$, Hakozaki H. Clinical and histopathological findings in Fabry's disease. Folia Ophthalmol Jpn 36: 502, 1985 (in Japanese).

18) Sumi K, Itou N, Takahashi M, et al. A case of Fabry's disease without angiokeratoma: clinical, biochemical and electronmicroscopic study. No to Hattatsu 18: 49, 1986 (in Japanese).

19) Yamanaka K, Inioe K, Yamada M, et al. Enzymatic and electron microscopic studies in Fabry's disease. Rinsho Hifuka 40(11): 967, 1986 (in Japanese).

20) Tamura $T$, Murayama $K$, Hayashi $M$, et al. Two cases of women with Fabry's disease detected by electrocardial abnormalities. J Jpn Soc Int Med 75: 1123, 1986 (in Japanese).

21) Aoyama A, Harada $T$, Awaya $S$, et al. Six cases from three family lines of Fabry's disease Ganka Rinshou Ihou 80(4): 666, 1986 (in Japanese).

22) Hozumi I. Clinical, histochemical and biochemical studies on symptomatic heterozygote of Fabry's disease. Niigata Igakukaizassi 101(7): 433, 1987 (in Japanese).

23) Narisawa H, Iriki A, Kohda H, et al. Fabry's disease. Hifubyou- shinryoh 10(6): 535, 1988 (in Japanese).

24) Yamada H, Oyama K, Shimizu H, et al. A case of Fabry's disease. Rinshou Hifuka 42(8): 701, 1988 (in Japancse).

25) Tanaka H, Adachi K, Yamashita Y, et al. Four cases of Fabry's disease mimicking hypertrophic cardiomyopathy. J Cardiol 18: 705, 1988 (in Japanese).

26) Iwase $M$, Yamauchi $K$, Maeda $M$, et al. Echocardiographic findings in a case of Fabry's disease with aortic regurgitation and complete AV block, and in his family members. J Cardiol 18: 589,1988 (in Japanese).

27) Tsuda $T$, Yokoyama A, Masani $\mathrm{H}$, et al. Myocardial involvement in female Fabry's disease: Evaluation by thallium-201 myocardial scintigraphy. J Cardiol 18: 135, 1988 (in Japanese).

28) Matsuyoshi $T$, Kawai $S$, Okamoto $H$, et al. A case of Fabry's discase, Acta Dermatol 83(4): 489, 1988 (in Japanese).

29) Ujin A, Watanabe $K$, Iwahashi $H$, et al. A pedigree of Fabry's disease. Jpn J Clin Ophthalmol 42(4): 1988 (in Japanese).

30) Yoshida K, Murase M, Masegi T, et al. Transvenous permanent pacemaker implantation for Fabry's disease. J Jpn Assoc Thorac Surg 37(2): 192, 1989 (in Japanese).

31) Nakanishi $T$, Nakai $K$, Shiomi J, et al. Fast atom bomberdment/ mass spectrometric (FAB/MS) analysis of glycosphingolipids in urine sediments from Fabry's disease patient. IRYO 43(11): 1214, 1989 (in Japanese).

32) Yamamoto K, Tanouchi J, Kagiya T, et al. A case of Fabry's disease manifested only with myocardial lesion. Heart 21(3), 1989 (in Japanese).

33) Yamada S, Itou $\mathrm{H}$, Ohashi $\mathrm{T}$, et al. A case of Fabry's disease detected by renal biopsy findings. Fukuokaishi 81(8), 266: 1990 (in Japanese).

34) Matsubara $M$, Taguma $Y$, Saito $T$, et al. Clinico-pathological features in four patients with Fabry's disease (The possible role of degenerative lesions in the interstitial vessels for renal dysfunction.). J Nephrol 17(2), 1990 (in Japanese).

35) Yamaguchi Y, Miyamura N, Sakai M, et al. A pedigree of Fabry's disease. Metabolism and Disease 28: 57, 1991 (in Japanese).

36) Kint JA, Carton D. Fabry's disease. In: Lysosome and Storage Disease, Hers HG, Van Hoof F, Eds. Academic Press, New York, 1973, p. 357. 